\title{
Glutathione and other low molecular weight thiols in marine phytoplankton under metal stress
}

\author{
Beth A. Ahner*, Liping Wei, Jessica R. Oleson, Nori Ogura \\ Department of Biological and Environmental Engineering, Cornell University, Ithaca, New York 14853, USA
}

\begin{abstract}
Low molecular weight intracellular sulfhydryl-containing compounds are responsible for the intracellular detoxification of metals such as $\mathrm{Cd}$ and $\mathrm{Cu}$ in eucaryotic phytoplankton. Glutathione, the most abundant thiol in non-stressed cells (0.8 to $2.8 \mathrm{mM})$, chelates metals directly, and also serves as the biochemical precursor from which phytochelatins are synthesized. Very little is known about physiological variations in glutathione concentrations under conditions of metal stress or other environmental factors. We found that in response to steady-state $\mathrm{Cd}$ and $\mathrm{Cu}$ exposure, glutathione concentrations remain remarkably constant in all of the algae examined, even as phytochelatin concentrations increase by up to 100 -fold control values (in some cases exceeding glutathione). In some species, $\gamma$-glu-cys and cysteine, precursors to glutathione, also increase significantly in response to metal exposure. Short-term exposure to $\mathrm{Cd}$ and $\mathrm{Cu}$ can have a dramatic effect on the intracellular glutathione and phytochelatin concentration especially when the culture is under nutrient limitation.
\end{abstract}

KEY WORDS: Glutathione $\cdot$ Phytochelatin $\cdot$ Thiols $\cdot$ Detoxification $\cdot$ Marine phytoplankton Resale or republication not permitted without written consent of the publisher

\section{INTRODUCTION}

Several recent papers have suggested that glutathione may be an important ligand for some metals in surface seawater (Le Gall \& van den Berg 1998, Leal et al. 1999, Tang et al. 2000) but relatively little is known about intracellular concentrations of glutathione or fluctuations thereof in marine phytoplankton. In the laboratory, concentrations are generally similar to those measured in higher plants and other organisms (Rijstenbil \& Wijnholds 1996) but environmental factors such as light and nutrient availability may be important in the field (Matrai \& Vetter 1988, Rijstenbil et al. 1998). Metal concentrations are also likely to play a role, since phytochelatins, metal-detoxification peptides, are produced from glutathione.

Glutathione ( $\gamma$-glutamylcysteinylglycine) is found in all eucaryotes and it is the most abundant small peptide and the dominant cellular thiol in many living

*E-mail: baa7@cornell.edu systems. It is typically present at millimolar concentrations within cells and can constitute up to $90 \%$ of nonprotein thiols (Giovanelli et al. 1980). The gamma linkage within glutathione confers an unusually high resistance to intracellular peptidases and thus it can be maintained at relatively high concentrations (Giovanelli et al. 1980). Glutathione is synthesized by the action of 2 enzymes: $\gamma$-glutamylcysteine synthetase and glutathione synthetase, which have been found to occur in the cytosol and chloroplasts of eucaryotic plant cells (Bergmann \& Rennenberg 1993).

Glutathione is a multifunctional tri-peptide and although not fully understood, its primary intracellular functions are as summarized in Fig. 1. One of its major roles is as a line of defense against reactive oxygen derivatives because of the ease with which glutathione undergoes oxidation and reduction reactions. The sulfhydryl group on the cysteine residue often functions as a site of conjugation, such as in the detoxification of organic compounds (e.g. herbicides) through the action of a family of enzymes called glutathione-Stransferases (Marrs 1996) and in its putative role as a 


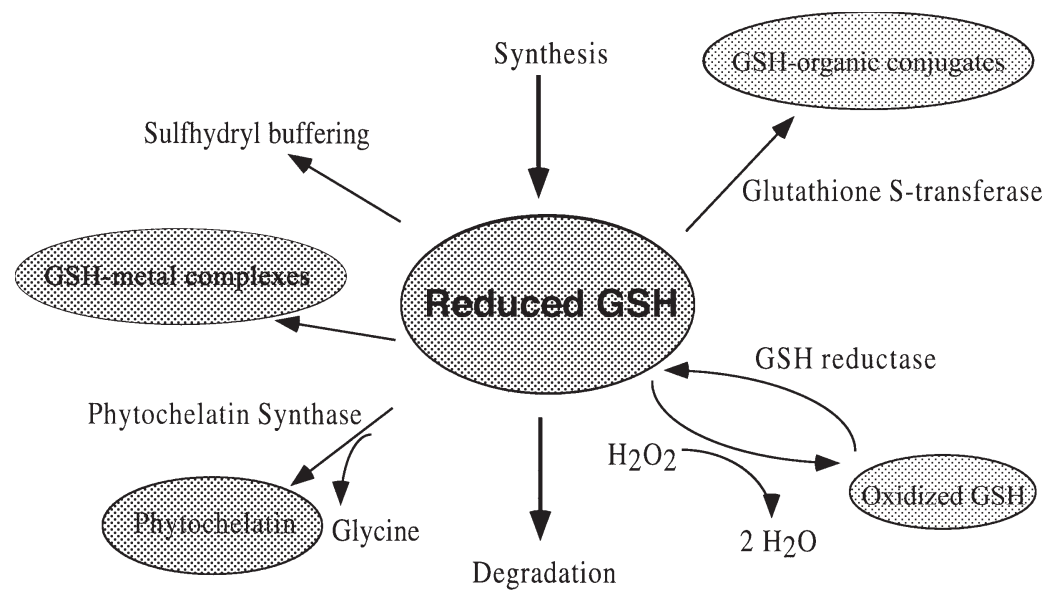

Fig. 1. Proposed functions and pools of glutathione (GSH) in a eucaryotic algal cell

carrier in the sulfate assimilation pathway (Giovanelli et al. 1980). In addition, glutathione is also the primary precursor from which phytochelatins are made. Phytochelatins are small, sulfhydryl-containing peptides with the formula ( $\gamma$-glutamylcysteinyl) $)_{\mathrm{n}}$-glycine, where $\mathrm{n}$ varies from 2 to 11 (Grill et al. 1985), although the $\mathrm{n}=$ 2, 3 and 4 oligomers are predominant in phytoplankton (Ahner et al. 1995). They are synthesized rapidly in response to some heavy metals (such as $\mathrm{Cd}$ and $\mathrm{Cu}$ ), even at very low concentrations, by the constitutive enzyme phytochelatin synthase that catalyzes the transfer of $\gamma$-glu-cys from glutathione to other glutathione molecules to form phytochelatin $\mathrm{n}=2$ or to $(\gamma \text {-glu-cys })_{n}$-gly polymers to form phytochelatin chains of length $n+1$ (Grill et al. 1989). Recent work by Vatamaniuk et al. (2000) using the purified recombinant phytochelatin synthase from Arabidopsis thaliana has shown that both the Cd-bis-glutathione complex and free glutathione serve as substrates for the enzyme, which explains the metal-dependent reaction mechanism. An additional synthesis mechanism, in which free $\gamma$-glu-cys units are polymerized and then a glycine residue is added by glutathione synthetase, has been identified in fission yeast (Hayashi et al. 1991). Glutathione availability in plant cells has been shown to limit metal tolerance and phytochelatin synthesis (Zhu et al. 1999).

Both glutathione and phytochelatin chelate heavy metals such as $\mathrm{Cd}, \mathrm{Cu}$, and $\mathrm{Pb}$ via sulfhydryl coordination (Rabenstein 1989; Strasdeit et al. 1991). While the binding constants for the various phytochelatin oligomers are not known, the longer peptides form stronger complexes with metals (Mehra et al. 1995). Given the abundance of glutathione in algal cells, it may be an important chelator of some metals. While studies of metal-stressed plants and algae have reported significant fluctuations in glutathione concen- tration upon the onset of phytochelatin synthesis (both increases and decreases have been observed: Ruegsegger et al. 1990, Rauser et al. 1991, Rijstenbil \& Wijnholds 1996), there have been few studies that have examined the effect of steady state exposure to metals on glutathione concentrations.

Ultimately a major source of glutathione in surface seawater is the eucaryotic phytoplankton. Here we examined the intracellular concentrations of glutathione and other low molecular weight thiols in several species of eucaryotic marine algae under steady state exposure to a range of $\mathrm{Cd}$ and $\mathrm{Cu}$ concentrations, as well as during short-term additions of these same metals. We also investigated whether other factors, such as light levels and nutrient status, influence glutathione and phytochelatin concentrations.

\section{MATERIALS AND METHODS}

Algal culture preparation. Several species of eucaryotic unicellular marine algae were cultured axenically at $120 \mu \mathrm{mol}$ photons $\mathrm{m}^{-2} \mathrm{~s}^{-1}$ and $19 \pm 1^{\circ} \mathrm{C}$ in Aquil, a defined medium developed specifically for studies of trace metal nutrition and toxicity in marine algae (Price et al. 1988/89). Species included the diatoms Phaeodactylum tricornutum and Thalassiosira pseudonana (both from Algensammlung [Collection of Algae] at Göttingen University, Germany), and $T$. weissflogii (CCMP 1336; Provasoli-Guillard National Center for Culture of Marine Phytoplankton, Bigelow Laboratory for Ocean Sciences, West Boothbay Harbor, Maine, USA). P. tricornutum is a pennate diatom, while T. pseudonana and T. weissflogii are centric diatoms. Emiliania huxleyi (CCMP 373) is a coccolithophore, or prymnesiophyte. Dunaliella sp. (CCMP 367) is a green alga of the order Volvocales. Approximate sizes and chlorophyll contents of the various species are given in Table 1. Culture medium and vessels were prepared to minimize metal contamination.

Aquil employs an EDTA buffer to fix trace metal concentrations in solution. $\mathrm{Cd}$ and $\mathrm{Cu}$ concentrations were varied in the medium by additions from stock solutions of equimolar $\mathrm{Cd}$ or $\mathrm{Cu}$ and EDTA (Table 2). When metals are buffered by EDTA, it ensures an approximate steady state supply of free metal ions in the medium as metals are removed by the algae. Equilibrium calculations were performed with MINEQL (Westall et al. 1976) to determine steady state concentrations of free metal ions $\left(\left[\mathrm{Me}^{2+}\right]\right.$, reported as $\left.\mathrm{pMe}=-\log \left[\mathrm{Me}^{2+}\right]\right)$. For 
Table 1. Cellular volume and chl a contents of algal species used in calculations of phytochelatin concentrations

\begin{tabular}{|lccc|}
\hline Phytoplankton species & Shape & $\begin{array}{c}\text { Volume }^{\mathrm{a}} \\
\left(\mu \mathrm{m}^{3}\right)\end{array}$ & $\begin{array}{c}\text { Chl } a \\
\left(\mathrm{pg} \mathrm{cell}^{-1}\right)\end{array}$ \\
\hline Dunaliella sp. & Ovate & 210 & 0.48 \\
Emiliania huxleyi (BT6) & Spherical & 13 & 0.075 \\
Phaeodactylum tricornutum & Elliptical & 160 & 0.23 \\
Thalassiosira pseudonana (3H) & Cylindrical & 73 & 0.26 \\
Thalassiosira weissflogii (Actin) & Cylindrical & 1230 & 4.0 \\
& & & \\
& & \\
aCalculated from average microscopic measurements of cell dimensions
\end{tabular}

dactylum tricornutum showed no significant loss of either glutathione or $\gamma$-glu-cys for up to $6 \mathrm{wk}$ of storage in liquid nitrogen (data not shown).

To study temporal variations of intracellular phytochelatin and glutathione in response to short-term metal exposure $(\mathrm{pMe}=9)$, Cd-EDTA or Cu-EDTA was added to exponential and stationary (5 to $6 \mathrm{~d}$ after the end of exponential growth) cultures grown in control medium. Cd incubations were performed with cultures of Thalassiosira pseudonana, Emiliania huxleyi, and Dunaliella sp. and $1 \mathrm{Cu}$

most metal-stressed cultures, the total trace metal concentrations were reduced 10-fold (resulting in $10 \mu \mathrm{M}$ EDTA as indicated in Table 2) in order to reduce the total EDTA concentration. The inorganic concentrations of all other metals were fixed at Aquil concentrations (Price et al. 1988/89). N, P, and Si concentrations were 10,300 and $100 \mu \mathrm{M}$ respectively.

To measure the variation of cellular glutathione and other low molecular weight thiols in response to steady state exposure to $\mathrm{Cd}$ and $\mathrm{Cu}$, algae were pre-cultured for at least 2 generations in $30 \mathrm{ml}$ polycarbonate tubes in medium containing added metals at the desired concentrations before transfer to $500 \mathrm{ml}$ acid-cleaned polycarbonate bottles containing the same experimental medium. Algae growth was monitored by measuring in vivo fluorescence (Turner 10-AU Fluorometer). Cell densities were determined microscopically with a Levy Hemacytometer (Hausser Scientific Company) and with a Coulter Counter (Coulter Electronics). Near the end of exponential growth, cells were collected by gentle filtration ( $<5 \mathrm{psi}$ ) onto $25 \mathrm{~mm}$ glass-fiber filters (Whatman GF/F or GF/A) and were frozen in liquid nitrogen. Frozen samples of Dunaliella sp. and Phaeo-

Table 2. Concentrations $(\mu \mathrm{M})$ of equimolar metal-EDTA added to achieve the listed free metal concentrations in Aquil. pMe is equivalent to $-\log \left[\mathrm{Me}^{2+}\right]$. TM EDTA indicates the concentration of EDTA present in the medium prior to adding $\mathrm{Cd}$ or $\mathrm{Cu}$. Compared to standard Aquil medium, 10-fold less trace metal mix is used for the 2 highest Cd treatments and all the $\mathrm{Cu}$ treatments

\begin{tabular}{|ccccc|}
\hline & $\mathrm{pMe}=12$ & $\mathrm{pMe}=11$ & $\mathrm{pMe}=10$ & $\mathrm{pMe}=9$ \\
\hline Cd & & & & \\
Cd-EDTA & 0.03 & 0.3 & 0.3 & 3 \\
TM EDTA & 100 & 100 & 10 & 10 \\
Cu & & & & \\
Cu-EDTA & 0.12 & 1.2 & 12 & 120 \\
TM EDTA & 10 & 10 & 10 & 10 \\
\hline
\end{tabular}

experiment was performed with E. huxleyi. Samples were collected by gentle filtration from $t=0$ to $36 \mathrm{~h}$ for thiol and chl a measurements. Samples from parallel control cultures were also collected.

Chl a was measured by extraction in aqueous acetone (Parsons et al. 1984). Filtered cells were placed into $10 \mathrm{ml}$ of cold $90 \%$ acetone (10\% water) and stored overnight at $4^{\circ} \mathrm{C}$ in the dark. Fluorescence was measured with a Turner fluorometer and the concentration of chl a was calculated using a calibration curve developed from a spectrophotometrically calibrated solution of chl a extracted from spinach.

Sample preparation for HPLC analysis. The samples were removed from storage in liquid nitrogen and immediately plunged into $2.5 \mathrm{ml}$ of $10 \mathrm{mM}$ methanesulfonic acid (MSA) at $70^{\circ} \mathrm{C}$ for $2 \mathrm{~min}$ to denature the proteins, before they were homogenized for 2 to $3 \mathrm{~min}$ using a Wheaton Overhead Stirrer in an ice-water bath. The resulting slurry was then centrifuged for $10 \mathrm{~min}$ at $13000 \mathrm{rpm}$ at $4^{\circ} \mathrm{C}$ (Biofuge Fresco, Heraeus Instruments), and the supernatant was retained and diluted, if necessary, with $10 \mathrm{mM}$ MSA for subsequent derivatization with monobromobimane $(\mathrm{mBBr})$ (Molecular Probes) generally following the protocol described in Ahner et al. (1995), which was originally based on the method of Newton et al. (1981). Changes from the method published by Ahner et al. (1995) included 10 -fold lower probe and reductant concentrations as well as the addition of excess dithiothreitol after the reaction incubation to utilize excess unreacted probe.

HPLC method. Samples were analyzed by reversephase HPLC on a $\mathrm{C}_{8}$ column $(2.1 \times 250 \mathrm{~mm}$, Alltech Solvent Miser). The compounds of interest were quantified by post-column fluorescence detection (Gilson, excitation 310 to $410 \mathrm{~nm}$ and emission 475 to $650 \mathrm{~nm}$ ) of the $\mathrm{mBBr}$ probe. The flow rate was constant at $0.2 \mathrm{ml}$ $\min ^{-1}$. A gradient of acetate buffer (Solution A: $0.25 \%$ acetic acid buffered to $\mathrm{pH}=4$ with $\mathrm{NaOH} ; 8 \%$ acetonitrile; $0.1 \mathrm{mM}$ tetrahexylammonium bromide, Aldrich Chemical) and $100 \%$ acetonitrile (Solution B) was used to separate thiols. The elution gradient used was as 
follows: 0\% B for $10 \mathrm{~min}$, a linear increase to $25 \% \mathrm{~B}$ over $5 \mathrm{~min}$, and another more gradual linear increase to $50 \%$ B over $50 \mathrm{~min}$. This was followed by an additional $30 \mathrm{~min}$ of $100 \%$ A to re-equilibrate the column. Glutathione, cysteine and $\gamma$-glu-cys (Sigma) and phytochelatin standards ( $\mathrm{n}=2,3$ and 4 ; synthesized by the New York Center for Advanced Technology, Biotechnology Program) were used to identify thiol peaks and to develop calibration curves for the conversion of peak area to concentration. Using a $200 \mu$ injection loop resulted in a detection limit of $\sim 1 \mathrm{pmol}$ of the $\mathrm{n}=2$ oligomer.

\section{RESULTS}

\section{Glutathione}

Five species of marine algae were exposed to variable concentrations of $\mathrm{Cd}$ and $\mathrm{Cu}$ and intracellular glutathione concentrations were measured. Control cultures (without metal addition) contained remarkably similar amounts of glutathione - from 475 to $725 \mu \mathrm{mol} \mathrm{g} \mathrm{chl} a^{-1}$ (Fig. 2). Although Dunaliella sp. appeared to have slightly higher concentrations than the other algae, an ANOVA analysis comparing control concentrations revealed no significant differences among algae ( $p>0.05)$. When concentrations were converted to umoles per cell volume, glutathione concentrations ranged from 0.78 to $2.4 \mathrm{mM}$ (780 to $2400 \mu \mathrm{M}$; Table 3). These values agree well with concentrations reported in other studies; for example, Rijstenbil \& Wijnholds (1996) reported values ranging from 0.1 to $3.3 \mathrm{mM}(100$ to $3300 \mu \mathrm{M})$ in 4 marine algae.

As $\mathrm{Cd}$ and $\mathrm{Cu}$ increased in the medium, there was relatively little change in glutathione concentrations and no truly discernable pattern of change among species (Fig. 2). Two-way ANOVA indicated no significant effect of $\mathrm{Cd}$ or $\mathrm{Cu}$ on glutathione ( $\mathrm{p}>0.05)$. However, for individual species there may be a dose-response. Glutathione in Emiliania huxleyi seemed to decrease at high $\mathrm{Cu}$ concentrations, while in Phaeodactylum tricornutum and Dunaliella sp. it showed an increase at $\mathrm{pCu}=9$ and $\mathrm{pCd}=9$, respectively.

\section{Cysteine and $\gamma$-glu-cys}

Concentrations of cysteine and $\gamma$-glu-cys in control cultures were significantly less than that of gluta-
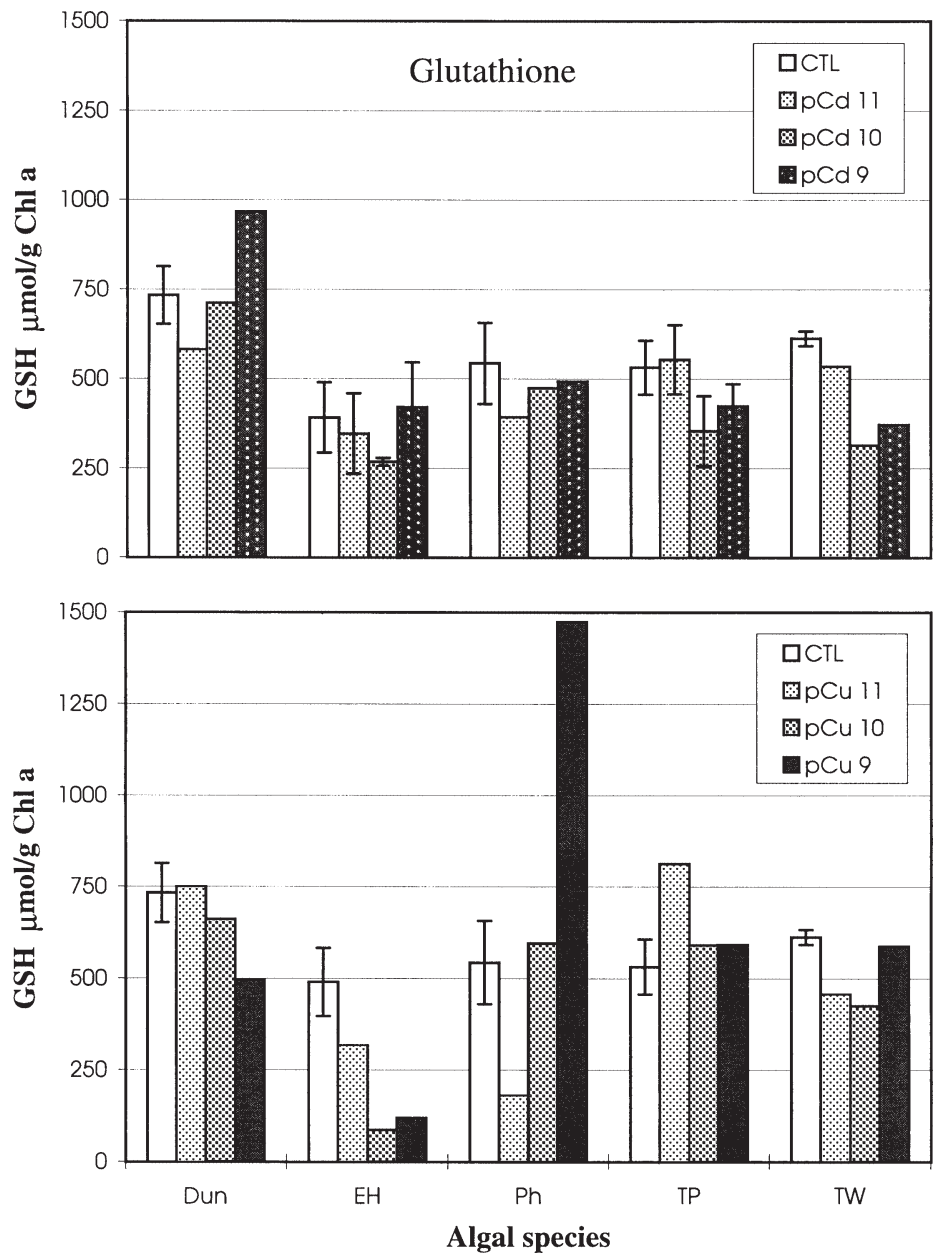

Fig. 2. Glutathione concentrations $\left(\mathrm{GSH}, \mu \mathrm{mol} \mathrm{gchl}^{-1}\right)$ in marine algae at varying concentrations of cadmium (top) and copper (bottom). Dun: Dunaliella sp.; EH: Emiliania huxleyi; Ph: Phaeodactylum tricornutum; TP: Thalassiosira pseudonana; TW: T. weissflogii. Error bars represent range of 2 (duplicate) cultures; data points without error bars were not duplicated

thione, and much more variability was observed among species (Fig. 3). In most of the algal species examined these compounds were 100-fold less than glutathione, whereas in Emiliania huxleyi cysteine concentrations were half and $\gamma$-glu-cys was about onethird that of glutathione. Measured concentrations of cysteine and $\gamma$-glu-cys ranged from below detection to $\sim 200 \mu \mathrm{mol} \mathrm{g} \mathrm{chl} \mathrm{a}^{-1}$.

In response to $\mathrm{Cd}$ exposure, both cysteine and $\gamma$-glucys increased with increasing amounts of Cd in Emiliania huxleyi, whereas only $\gamma$-glu-cys increased in Thalassiosira weissflogii and Phaeodactylum tricornutum. Concentrations remained constant in T. pseudonana and remained below detection in Dunaliella sp. In $E$. huxleyi, both $\gamma$-glu-cys and cysteine exceeded glutathione concentrations at the highest Cd concentra- 
Table 3. Glutathione (GSH), phytochelatin and metal concentrations $(\mu \mathrm{M})$ in each alga. Values are $\mu$ mol per cell volume; conversions from values in Figs. 2 to 4 based on cellular volume of control cells in Table 2. Total phytochelatin (PC) is the sum of the $\gamma$-glu-cys units in the individual oligomers $\left(\sum \gamma\right.$-glu-cys $\left.=2[n=2]+3[n=3]+4[n=4]\right)$ where $n=$ number of repeating units bd: below detection

\begin{tabular}{|c|c|c|c|c|c|c|}
\hline Species & GSH & $\mathrm{n}=2$ & $\mathrm{n}=3$ & $\mathrm{n}=4$ & Total PC & Metal \\
\hline \multicolumn{7}{|l|}{ Dunaliella sp. } \\
\hline Control & 1700 & 2.7 & 1.2 & 0.23 & 10 & \\
\hline $\mathrm{pCd}=12^{\mathrm{a}}$ & 1700 & 2.3 & 2.7 & 1.5 & 19 & \\
\hline $\mathrm{pCd}=11$ & 1300 & 14 & 5.3 & 5.4 & 66 & \\
\hline $\mathrm{pCd}=10$ & 1600 & 47 & 29 & 52 & 390 & \\
\hline $\mathrm{pCd}=9$ & 2200 & 61 & 65 & 56 & 540 & \\
\hline $\mathrm{pCu}=12$ & 1500 & bd & $\mathrm{bd}$ & $\mathrm{bd}$ & bd & \\
\hline $\mathrm{pCu}=11$ & 1700 & $\mathrm{bd}$ & $\mathrm{bd}$ & $\mathrm{bd}$ & $\mathrm{bd}$ & \\
\hline $\mathrm{pCu}=10$ & 1500 & 33 & 14 & 2.9 & 120 & \\
\hline $\mathrm{pCu}=9$ & 1100 & 30 & 6.9 & 0.78 & 84 & \\
\hline \multicolumn{7}{|c|}{ Emiliania huxleyi } \\
\hline Control & 2400 & bd & bd & $\mathrm{bd}$ & bd & \\
\hline $\mathrm{pCd}=11$ & 2000 & 320 & 180 & 270 & 2300 & $460^{\mathrm{b}}$ \\
\hline $\mathrm{pCd}=10$ & 1500 & 410 & 490 & 560 & 4500 & $1000^{b}$ \\
\hline $\mathrm{pCd}=9$ & 2400 & 430 & 470 & 240 & 3200 & $640^{\mathrm{b}}$ \\
\hline $\mathrm{pCu}=11$ & 1800 & $\mathrm{bd}$ & $\mathrm{bd}$ & $\mathrm{bd}$ & bd & $280^{\mathrm{b}}$ \\
\hline $\mathrm{pCu}=10$ & 500 & 290 & 310 & 230 & 2400 & $2100(10.5)^{\mathrm{C}}$ \\
\hline $\mathrm{pCu}=9$ & 690 & 46 & 58 & 17 & 330 & \\
\hline \multicolumn{7}{|c|}{ Phaeodactylum tricornutum } \\
\hline Control & 780 & 6 & 4.2 & 4.4 & 42 & \\
\hline $\mathrm{pCd}=11$ & 560 & 2.2 & bd & 0.69 & 7.1 & \\
\hline $\mathrm{pCd}=10$ & 680 & 43 & 4.0 & 6.4 & 120 & \\
\hline $\mathrm{pCd}=9$ & 710 & 40 & 3.6 & 8.0 & 120 & \\
\hline $\mathrm{pCu}=11$ & 260 & 41 & 32 & 8.1 & 210 & \\
\hline $\mathrm{pCu}=10$ & 860 & 88 & 22 & 6.3 & 270 & \\
\hline $\mathrm{pCu}=9$ & 2100 & 160 & 87 & $\mathrm{bd}$ & 580 & \\
\hline \multicolumn{7}{|c|}{ Thalassiosira pseudonana } \\
\hline Control & 1900 & 44 & 5.3 & 2.2 & 110 & \\
\hline $\mathrm{pCd}=12$ & 2100 & 53 & 14 & bd & 147 & $0.56^{\mathrm{d}}$ \\
\hline $\mathrm{pCd}=11$ & 2000 & 820 & 230 & 7 & 2300 & $7^{\mathrm{d}}$ \\
\hline $\mathrm{pCd}=10$ & 1300 & 1700 & 1300 & 200 & 8100 & $70^{\mathrm{d}}$ \\
\hline $\mathrm{pCd}=9$ & 1500 & 1500 & 1800 & 330 & 9700 & \\
\hline $\mathrm{pCu}=11$ & 2900 & 110 & bd & bd & 220 & $250^{\mathrm{c}}$ \\
\hline $\mathrm{pCu}=10$ & 2100 & 400 & 240 & 29 & 1600 & \\
\hline $\mathrm{pCu}=9$ & 2100 & 350 & 270 & 27 & 1600 & \\
\hline \multicolumn{7}{|c|}{ Thalassiosira weissflogii } \\
\hline Control & 2000 & bd & bd & bd & bd & \\
\hline $\mathrm{pCd}=12$ & 1800 & 44 & 36 & 15 & 250 & $15^{\mathrm{b}}$ \\
\hline $\mathrm{pCd}=11$ & 1700 & 200 & 25 & 7.7 & 500 & $16^{\mathrm{b}}$ \\
\hline $\mathrm{pCd}=10$ & 1000 & 970 & 450 & 160 & 3900 & $25^{\mathrm{b}}$ \\
\hline $\mathrm{pCd}=9$ & 1200 & 1200 & 690 & 140 & 5000 & $64^{\mathrm{b}}$ \\
\hline $\mathrm{pCu}=12$ & 1900 & bd & $\mathrm{bd}$ & bd & bd & $4.6^{\mathrm{c}}$ \\
\hline $\mathrm{pCu}=11$ & 1500 & 15 & 13 & 5.9 & 93 & $50^{c}$ \\
\hline $\mathrm{pCu}=10$ & 1400 & 28 & 12 & 5.9 & 120 & $177(10.5)^{\mathrm{C}}$ \\
\hline $\mathrm{pCu}=9$ & 1900 & 15 & 15 & 6.8 & 100 & \\
\hline $\begin{array}{l}{ }^{\mathrm{a}} \mathrm{pCd}=-\log [\mathrm{C} \\
{ }^{\mathrm{b}} \mathrm{Ahner} \text { et al. } \\
{ }^{\mathrm{c}} \text { Sunda \& Hu} \\
{ }^{\mathrm{d}} \text { Sunda \& Hu }\end{array}$ & $\begin{array}{l}\text { edium } \\
\text { parent }\end{array}$ & etal conc & of $\mathrm{m}$ & liffere & le & \\
\hline
\end{tabular}



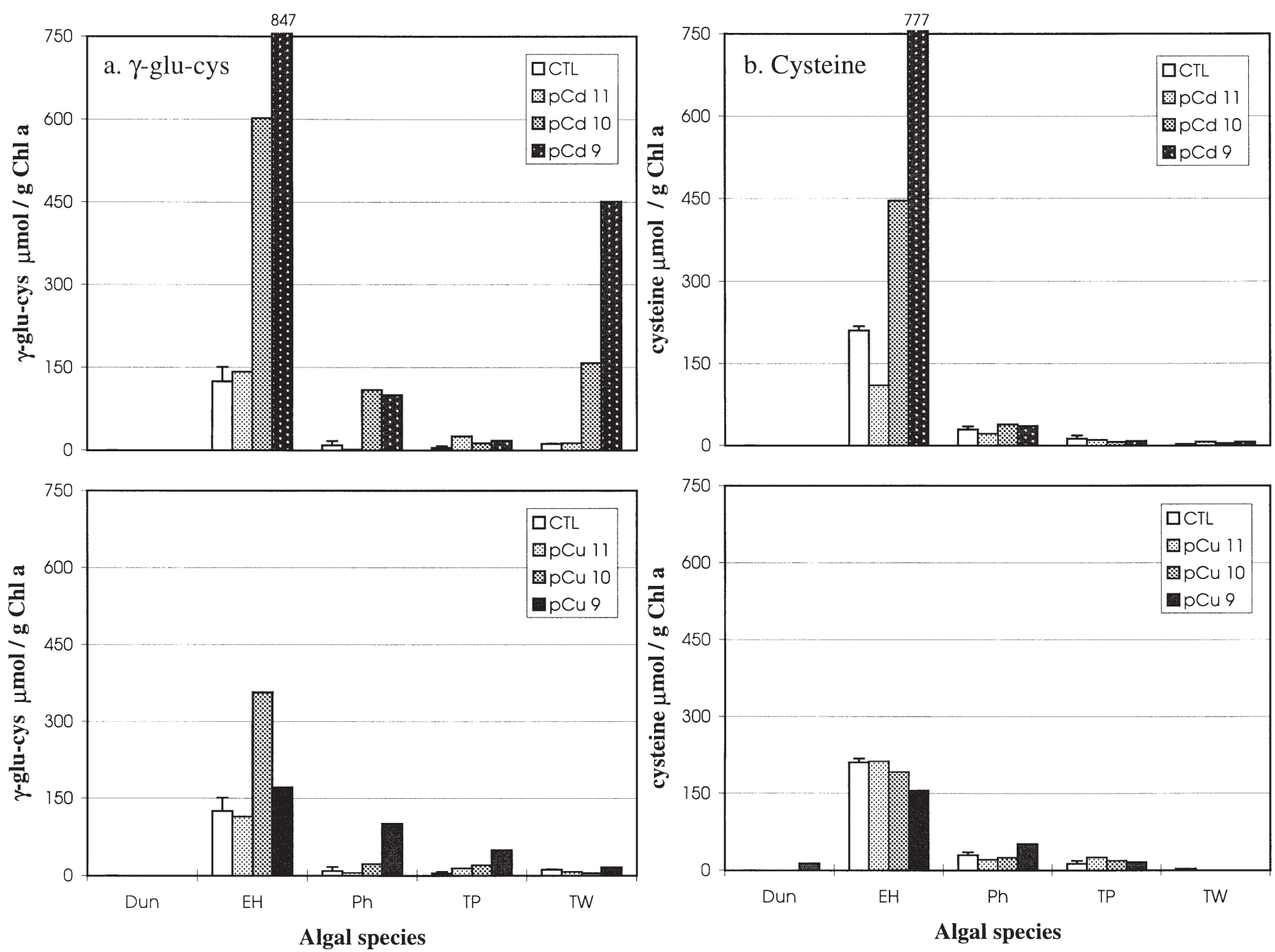

Fig. 3. Concentrations ( $\mu \mathrm{mol} \mathrm{g} \mathrm{chl} a^{-1}$ ) of $\gamma$-glu-cys (a), and cysteine (b) in marine algae at varying concentrations of cadmium (top) and copper (bottom). The off scale data points in (a) and (b) are as indicated on the graph. Abbreviations and error bars are as in Fig. 2. The absence of a bar indicates that the compound was below detection. Note difference in $y$-axis scale for these graphs compared to Figs. 2 \& 4

tion. Cysteine concentrations in a later experiment with a culture of $E$. huxleyi grown in a light:dark cycle (16:8) were 1056, 2262, 1439 and $1932 \mu \mathrm{mol} \mathrm{g} \mathrm{chl} \mathrm{a}^{-1}$ with increasing $\mathrm{Cd}$. These higher values may be the result of a diurnal cycle in cysteine concentrations (cultures in Fig. 3b were grown under constant light). Rates of sulfate reduction and assimilation follow a diurnal cycle in higher plants (Kopriva et al. 1999).

In response to $\mathrm{Cu}$, again the greatest response was seen in Emiliania huxleyi for $\gamma$-glu-cys (Thalassiosira pseudonana and Phaeodactylum tricornutum increased slightly at the highest $\mathrm{Cu}$ concentration), but concentrations of cysteine remained constant for all algae at all $\mathrm{Cu}$ concentrations. The more frequently observed increase in $\gamma$-glu-cys is consistent with other published experiments in which $\gamma$-glu-cys synthetase activity was more stimulated than the activities of other enzymes in the biosynthetic pathway of glutathione in Cd-exposed tissues (Schäfer et al. 1998).

\section{Phytochelatin}

Phytochelatins were measured in control cultures of Dunaliella sp., Thalassiosira pseudonana and Phaeodactylum tricornutum, but were below detection in the other 2 species (Table 3). Our inability to measure phytochelatin in the control cultures of T. weissflogii and Emiliania huxleyi was likely due to insufficient biomass in those particular samples, since, in an earlier 
study employing the same growth medium, these organisms were found to contain 13 and $40 \mu \mathrm{mol} \gamma$-glu-cys gchl $a^{-1}$ as phytochelatin respectively (Ahner et al. 1995).

Upon exposure to $\mathrm{Cd}$ or $\mathrm{Cu}$ there was a significant increase in the intracellular concentration of phytochelatin in each of the species studied (Fig. 4), confirming the results of Ahner et al. (1995). In general, absolute quantities of phytochelatin synthesized in response to $\mathrm{Cu}$ are lower than in $\mathrm{Cd}$-stressed cells. The one exception to this trend was Phaeodactylum tricornutum, which produced the least amount of phytochelatin in response to $\mathrm{Cd}$ and was among those producing the most in response to $\mathrm{Cu}$. Dunaliella sp. and Thalassiosira weissflogii synthesized very little phytochelatin in response to $\mathrm{Cu}_{\text {; }}$ it is possible that these organisms utilize some alternate detoxification strategy for $\mathrm{Cu}$. Decreases observed in phytochelatin at the highest $\mathrm{Cd}$ and $\mathrm{Cu}$ concentrations in Emiliania huxleyi and a slight decrease observed by Ahner \& Morel (1995) at the highest $\mathrm{Cu}$ concentration in T. weissflogii is also evidence that direct intracellular chelation by phytochelatin alone is not the only detoxification mechanism at work.

\section{Time-course experiments}

Short-term metal addition experiments were performed to examine how glutathione and other thiol constituents varied as function of time after exposure to $\mathrm{Cd}$ and $\mathrm{Cu}$. These experiments were performed on exponentially growing cells and on cultures that had been in a stationary phase for 5 to $6 \mathrm{~d}$; this allowed us to compare cells that were presumably nutrient-sufficient to those that were limited by 1 or more nutrients. $\mathrm{Cd}$ addition experiments were performed on Thalassiosira pseudonana, Emiliania huxleyi, and Dunaliella sp. and a $\mathrm{Cu}$ addition experiment was performed on $E$. huxleyi.

Senescent and exponential cultures of Thalassiosira pseudonana responded very similarly upon exposure to $\mathrm{Cd}$ with respect to glutathione and phytochelatin production (Fig. 5). Starting concentrations of glutathione were roughly the same in both cultures; they gradually decreased over the first $10 \mathrm{~h}$ and then leveled off. Phytochelatin increased in both cultures at the same rate and the final concentrations approached the steady state concentration measured at $\mathrm{pCd}=9$. The final phytochelatin concentration in the exponential
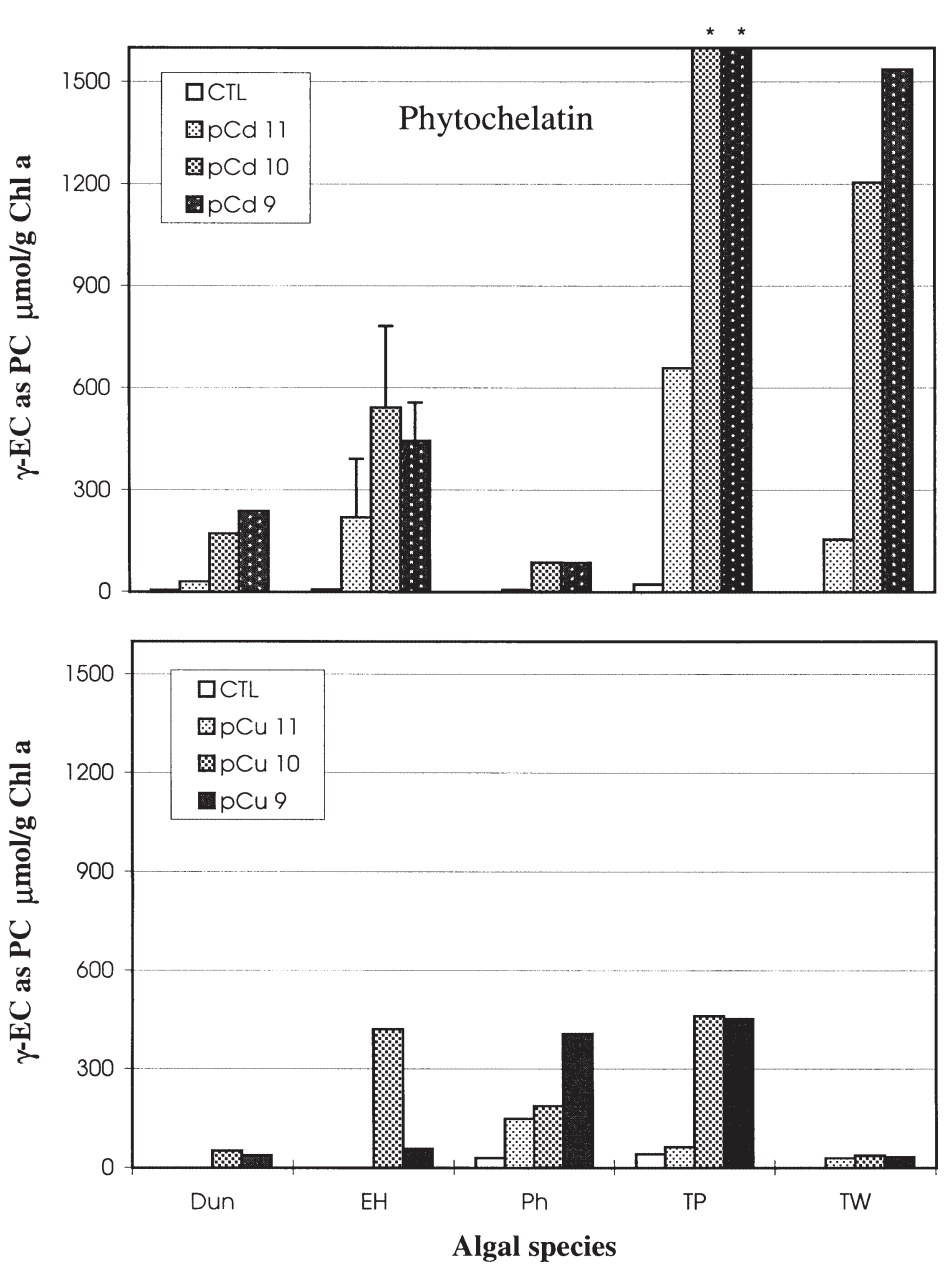

Fig. 4. Concentrations ( $\mu \mathrm{mol} \mathrm{g} \mathrm{chl}^{-1}$ ) of phytochelatin, in units of $\gamma$-glucys $\left(\sum \gamma-\mathrm{EC}=2[\mathrm{n}=2]+3[\mathrm{n}=3]+4[\mathrm{n}=4]\right)$ in marine algae at varying concentrations of cadmium (top) and copper (bottom). Abbreviations and error bars are as described in Fig. 2. *: off-scale values of total $\gamma$-EC are 2300 and $2700 \mu \mathrm{mol} \mathrm{g} \mathrm{chl} a^{-1}$ for pCd 10 and 9 respectively

cells was slightly higher than in the senescent cells and the reverse was true for the glutathione. In control cultures (no added $\mathrm{Cd}$ ) glutathione remained constant and phytochelatin was below detection for the duration of the experiment (data not shown).

As with Thalassiosira pseudonana, in both exponential and senescent Cd-treated cultures of Dunaliella sp., glutathione was maintained at very similar levels after 10 and $30 \mathrm{~h}$ of exposure. However, after this same time interval, phytochelatin was 10 to 20 times higher in the exponential culture than in the senescent culture (data not shown).

For Emiliania huxleyi, on the other hand, after the first few hours of exposure to Cd both glutathione and phytochelatin were significantly higher in the exponential culture than in the senescent culture (Fig. 6). In both cultures the glutathione declined initially, but in 


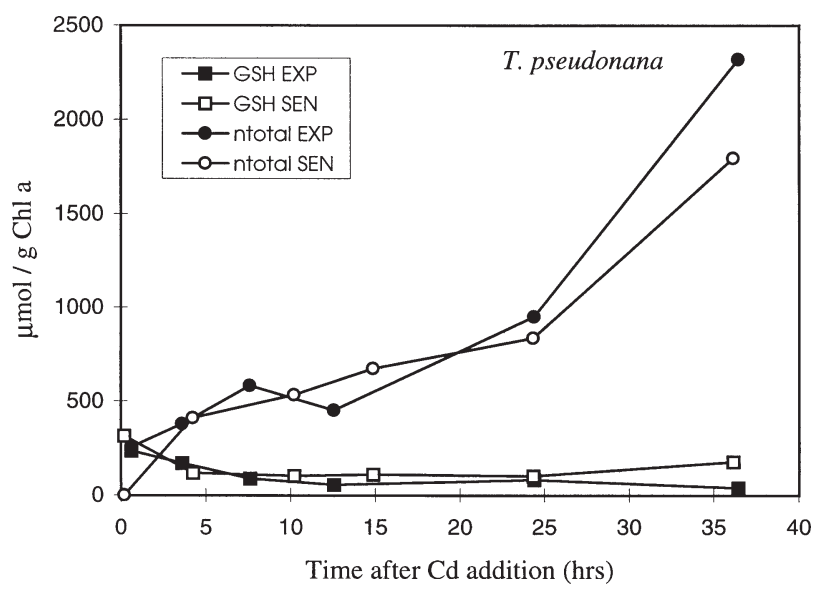

Fig. 5. Thalassiosira pseudonana. Time course of glutathione $(\mathrm{GSH})$ and phytochelatin (ntotal $=\sum \gamma-\mathrm{EC}=2[\mathrm{n}=2]+3[\mathrm{n}=3]$ $+4[\mathrm{n}=4])$ concentrations upon exposure to $\mathrm{pCd}=9$ at $t=0$. Filled symbols represent concentrations in exponentially growing cells and open symbols concentrations in senescentphase cells. Upon Cd addition, chl a increased similarly in both treated and control exponential cultures, whereas it remained constant in both the treated and control senescent cultures (data not shown)

the exponential culture glutathione recovered dramatically (peaking at $5 \mathrm{~h}$ ) and then maintained a constant though elevated concentration from 10 to $36 h_{\text {; }}$ in the senescent culture, glutathione continued to decrease and then leveled off after $10 \mathrm{~h}$. Phytochelatin peaked early in the senescent culture ( $t=1 \mathrm{~h})$ and then tapered off, while in the exponential culture it peaked at $5 \mathrm{~h}$ and then gradually climbed back to near $700 \mu \mathrm{mol}$ $\mathrm{gchl} \mathrm{a}^{-1}$. Final concentrations of both glutathione and phytochelatin were similar to those measured in steady state cultures at the same $\mathrm{Cd}$ concentration.

Similar to what we observed with Cd addition, exponentially growing Emiliania huxleyi synthesized excess glutathione in response to $\mathrm{Cu}$, while the senescent cells steadily lost glutathione (Fig. 7). Phytochelatin was rapidly produced by the exponential cells over the first $5 \mathrm{~h}$ and then leveled off at near steady state values $\left(\sim 100 \mu \mathrm{mol} \mathrm{g} \mathrm{chl} \mathrm{a}^{-1}\right)$ (data not shown). In senescent cells, phytochelatin was below detection for the entire experiment.

In the Cd experiment, it is unclear whether the peak at $5 \mathrm{~h}$ in Fig. 6 was real or an artifact, since these experiments were not duplicated. However, a similar peak also appeared for $\gamma$-glu-cys in the Cd experiment as well as for $\gamma$-glu-cys, cysteine, and phytochelatin in the $\mathrm{Cu}$ addition experiment (data not shown).

Sensitivity to metals was also different among the species examined. Growth rates were unaltered by the addition of $\mathrm{Cd}$ to the exponential cultures of both Thalassiosira pseudonana and Dunaliella sp. and the chl a concentration remained constant in both the treated
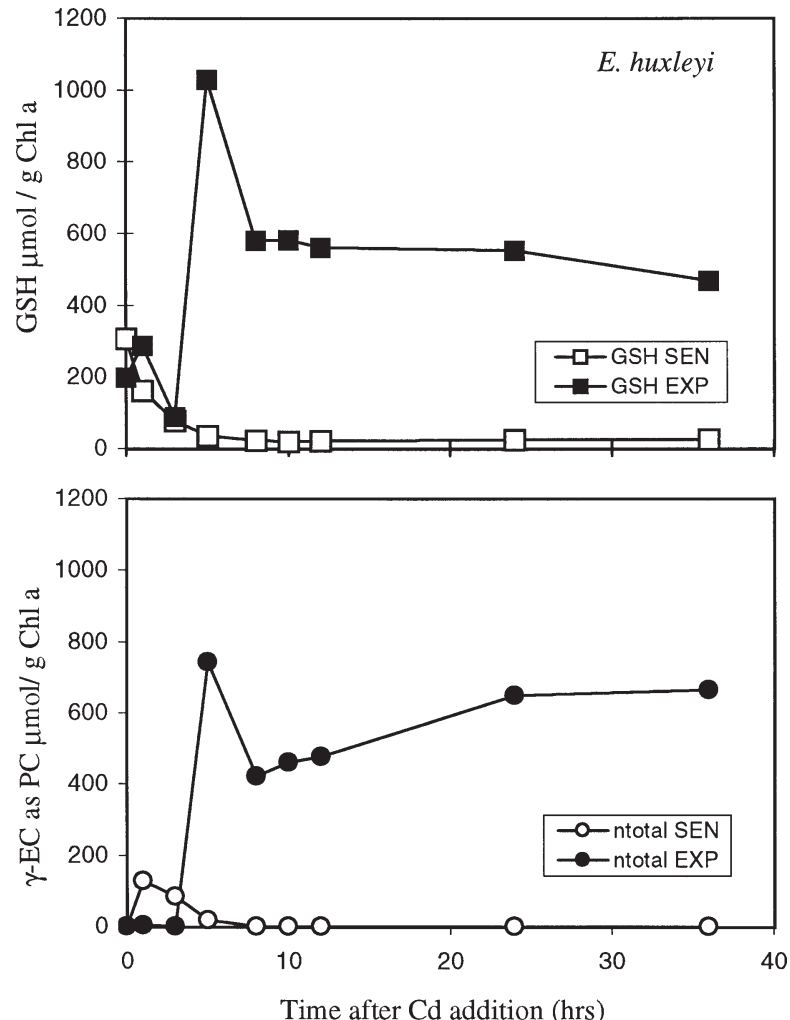

Fig. 6. Emiliania huxleyi. Time course of glutathione $\left(\mathrm{GSH}_{;}\right.$ top) and phytochelatin (ntotal $=\sum \gamma-\mathrm{EC}=2[\mathrm{n}=2]+3[\mathrm{n}=3]+$ 4 [n $=4$ ]; bottom) concentrations upon exposure to $\mathrm{pCd}=9$ at $t=0$. Filled symbols represent concentrations in exponentially growing cells and open symbols concentrations in senescentphase cells. Upon Cd addition, the growth rate of exponential cells (as determined by chl a) decreased by $35 \%$ compared to control. Total chl a decreased steadily in both treated and control senescent cells (data not shown)

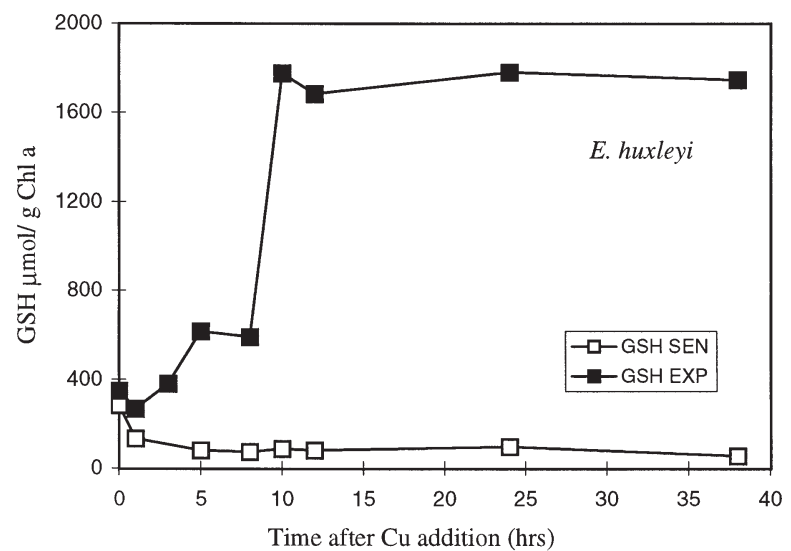

Fig. 7. Emiliania huxleyi. Time course of glutathione (GSH) concentrations upon exposure to $\mathrm{pCu}=9$ at $t=0$. $\mathbf{\square}$ : concentrations in exponentially growing cells; $\square$ : concentrations in senescent-phase cells. Upon $\mathrm{Cu}$ addition, chl a initially declined in treated exponential cells and then recovered after $5 \mathrm{~h}$, resuming growth at a rate about one-third that of controls (data not shown). Chl $a$ in treated and control senescent cultures decreased similarly (data not shown) 
and control senescent cultures. Emiliania huxleyi, on the other hand, appeared to be sensitive to $\mathrm{Cd}$ and $\mathrm{Cu}$ additions. Relative to controls, growth rates decreased in both $\mathrm{Cd}$ - and $\mathrm{Cu}$-treated exponential cultures (details in Fig. 6 and 7 legends). A decrease in chl a was observed in both treated and control senescent cultures. It is possible that the sensitivity of E. huxleyi to the added metals contributed to the observed differences in glutathione and phytochelatin.

\section{DISCUSSION}

Intracellular glutathione concentrations are quite similar from species to species and in general are not significantly altered by long-term exposure to $\mathrm{Cd}$ and $\mathrm{Cu}$. Glutathione appears to be tightly regulated, despite substantial utilization for phytochelatin synthesis, which is consistent with the cell's need to maintain glutathione for other essential functions. Conversely, $\gamma$-glu-cys and cysteine (in 1 case), the main precursors of glutathione are significantly elevated in some algae in response to metal exposure. As in earlier studies, greater phytochelatin production is generally observed in response to $\mathrm{Cd}$ rather than $\mathrm{Cu}$, although Phaeodactylum tricornutum is a noted exception in this study.

Perturbations in glutathione concentrations are observed during metal addition experiments and under conditions of nutrient limitation. We observed that some species are unable to synthesize phytochelatin or maintain high levels of glutathione once the culture has reached senescence. One clear limitation of using senescent cultures in these experiments is that we have not imposed a particular nutrient limitation. Of the 3 algae examined, senescent Thalassiosira pseudonana cells appear uniquely able to maintain glutathione and also produce copious amounts of phytochelatin upon addition of cadmium. As silica frustule-forming diatoms, they are ultimately limited by silicate in our culture medium whereas the other species examined are more likely to be limited by nitrogen or phosphorus $(\mathrm{N}$. Price pers. comm.). Nitrogen limitation has been found to limit sulfate assimilation (Koprivova et al. 2000) and thus may limit glutathione synthesis (Rijstenbil et al. 1998), although nitrogen in glutathione represents a very small fraction of the total cellular nitrogen $(<0.5 \%$ in $T$. weissflogii). In follow-up experiments, batch cultures of nitrogen-limited T. pseudonana did not exhibit lower glutathione or phytochelatin production upon $\mathrm{Cd}$ addition (data not shown). Phosphorus limitation, on the other hand, may cause ATP deficiencies that might disrupt membrane transport processes in addition to limiting sulfate reduction, the first step of which involves ATP (Giovanelli et al. 1980).
Although glutathione remains constant, phytochelatin concentrations are highly variable among species, especially at high $\mathrm{Cu}$ and $\mathrm{Cd}$ concentrations. A comparison of $\mathrm{Cu}$-challenged Thalassiosira weissflogii and Emiliania huxleyi reveals fairly large differences in phytochelatin concentrations that are also observed in cellular Cu concentrations (Sunda \& Huntsman 1995; data reported in Table 3). Remarkably, phytochelatin and $\mathrm{Cu}$ concentrations are very similar. This is not entirely surprising since phytochelatin production is dependent on the presence of metals in the cell. Not all differences in phytochelatin production, however, can be explained by differences in metal quotas. Other detoxification mechanisms will also affect total phytochelatin concentrations. Cd has been shown to accumulate in vacuoles as a complex with phytochelatin (Salt \& Wagner 1993, Ortiz et al. 1995), as ionic Cd (Salt \& Rauser 1995) and as a glutathione complex (Li et al. 1997 ) in yeast and higher plants. In addition, the more stable sulfide-containing phytochelatin-metal clusters (Reese \& Winge 1988) may be produced by some algae, which would result in less total phytochelatin. Also, other intracellular chelators may be synthesized; metallothionein genes have been found in several eucaryotic plants (e.g. Zhou \& Goldsbrough 1995) and metallothioneins have a greater affinity for both $\mathrm{Cd}$ and $\mathrm{Cu}$ than the phytochelatins (Weber et al. 1988).

One observation that is difficult to explain with any of the above mechanisms is the large excess of phytochelatin produced in some algae in response to $\mathrm{Cd}$ (Table 3). At pCd 11 and 10, phytochelatin concentrations in Thalassiosira pseudonana are 2300 and $8100 \mu \mathrm{M}$ respectively whereas $\mathrm{Cd}$ concentrations, as measured by Sunda \& Huntsman (1998), are 7 and $70 \mu \mathrm{M}$ ( $\mu \mathrm{mol}^{-1}$ cell volume). Assuming an optimal 4:1 stoichiometry of cysteinyl-S: Cd (Strasdeit et al. 1991), these phytochelatin concentrations are 80 and 30 times greater than needed for direct complexation. Similar ratios were observed in $T$. weissflogii (Table 3 and Ahner et al. 1995) but not in the related species $T$. oceanica (Ahner et al. 1995). One possible explanation for this observation is that the phytochelatin synthase in these 2 closely related organisms ( $T$. weissflogii and T. pseudonana) does not require the Cd-(glutathione) ${ }_{2}$ complex as a substrate (as does the Arabidopsis form: Vatamaniuk et al. 2000) and the production of the enzyme is under transcriptional control. It is also possible that phytochelatin synthesis in these organisms proceeds via $\gamma$-glu-cys polymerization, as has been observed in fission yeast (Hayashi et al. 1991). This could explain the high ratio of phytochelatin to $\mathrm{Cd}$ observed in $T$. weissflogii (the forward reaction may be driven by excess substrate), but does not explain the $T$. pseudonana data, nor does excess $\gamma$-glu-cys in Emiliania huxleyi result in high $\mathrm{Cd}$ to phytochelatin ratios. 
Further studies on the properties of phytochelatin synthase in marine algae are now possible, since several genes for phytochelatin synthase have been identified (Cobbett 2000). Utilizing conserved regions present in all of the sequenced enzymes, we may be able to obtain the sequence for the synthase in Thalassiosira weissflogii and characterize its apparently unique activity.

Particulate concentrations of glutathione in the field are lower than those measured in this study. Matrai \& Vetter (1988) reported concentrations of 40 to $100 \mu \mathrm{mol}$ $\mathrm{g} \mathrm{chl} a^{-1}$ in surface waters of Saanich Inlet and 100 to $200 \mu \mathrm{mol} \mathrm{g} \mathrm{chl} a^{-1}$ in surface waters of the Southern California Bight (calculated from values plotted in graphs). Tang et al. (2000) measured very low glutathione concentrations in Galveston Bay, Texas, $\sim 10 \mu \mathrm{mol} \mathrm{g} \mathrm{chl} \mathrm{a}^{-1}$, with concentrations increasing up to $\sim 170 \mu \mathrm{mol} \mathrm{g} \mathrm{chl} \mathrm{a}^{-1}$ at the mouth of the bay. In addition, we found that glutathione concentrations in the Elizabeth River and the lower Chesapeake Bay, near Norfolk, Virginia, were also low (2 to $15 \mu \mathrm{mol} \mathrm{g} \mathrm{chla}^{-1}$; unpubl. data). While the group of algae examined in this study may not necessarily be representative of coastal assemblages, the lower concentrations in the field as compared to the laboratory data (as well as the lower near-shore and estuarine concentrations compared to the more oceanic measurements) could be due to some nutrient limitation combined with some stress that depletes glutathione. Measurements of phytochelatin in the field are also typically lower than those in the laboratory (Ahner et al. 1997), but it remains to be determined whether this is a direct result of the lower glutathione concentrations. Concentrations of particulate $\gamma$-glu-cys were significantly higher than glutathione in Galveston Bay (Tang et al. 2000). In the laboratory cultures, this was only found when the cultures were challenged with metals.

Several recent research papers have suggested that glutathione may be a fairly abundant ligand in surface seawater (Le Gall \& van den Berg 1998, Leal et al. 1999, Tang et al. 2000). Le Gall \& van den Berg (1998) measured up to $15 \mathrm{nM}$ glutathione in coastal surface water using an electrochemical technique, and Tang et al. (2000) measured up to $6 \mathrm{nM}$ in Galveston Bay using a sensitive HPLC method. There does appear to be somewhat of a conundrum with respect to the source of this dissolved glutathione. Particulate concentrations (normalized to volume) are less than those measured in the dissolved phase (Tang et al. 2000) and, even using the high intracellular concentrations measured in this paper and conservative estimates of turnover rates, it is difficult to predict such high concentrations. Further work should be done to determine the chemical and biological stability of these compounds in the field. It is possible that we are underestimating the source terms in our calculations. Indeed, very high rates of glutathione efflux must be invoked to explain the rapid increase in dissolved ligand concentrations observed by Vasconcelos \& Leal (2001) in response to Cu additions to Emiliania huxleyi cultures that were attributed to a glutathione-like compound.

In conclusion, low molecular weight thiols are very important biochemicals and, through laboratory studies, we have come one step closer to understanding the potential influence of some environmental variables on their intracellular concentrations.

Acknowledgements. Funding for this project was obtained through a National Defense Science and Engineering Graduate Fellowship to J.R.O. and a Sage Fellowship to L.W. from the Cornell University Graduate School. N.O. received funding through the Cornell University, College of Agriculture and Life Sciences, Undergraduate Honors Research Program. We would also like to thank our reviewers for supportive and helpful comments.

\section{LITERATURE CITED}

Ahner BA, Morel FMM (1995) Phytochelatin production in marine algae. II. Induction by various metals. Limnol Oceanogr 40:658-665

Ahner BA, Kong S, Morel FMM (1995) Phytochelatin production in marine algae. I. An interspecies comparison. Limnol Oceanogr 40:649-657

Ahner BA, Morel FMM, Moffett JW (1997) Trace metal control of phytochelatin production in coastal waters. Limnol Oceanogr 42:601-608

Bergmann L, Rennenberg H (1993) Glutathione metabolism in plants. In: De Kok LJ, et al. (eds) Sulfur nutrition and assimilation in higher plants. SPB Academic Publishing bv, The Hague, p 109-123

Cobbett CS (2000) Phytochelatins and their roles in heavy metal detoxification. Plant Physiol 123:825-832

Giovanelli J, Mudd SH, Datko AH (1980) Sulfur amino acids in plants. In: Stumpf PE, Conn EE (eds) The biochemistry of plants: a comprehensive treatise, Vol 5. Academic Press, New York, p 453-505

Grill E, Winnacker EL, Zenk MH (1985) Phytochelatins: the principal heavy-metal complexing peptides of higher plants. Science 230:674-676

Grill E, Loeffler S, Winnacker EL, Zenk MH (1989) Phytochelatins, the heavy-metal-binding peptides of plants, are synthesized from glutathione by a specific $\gamma$-glutamylcysteine dipeptide transpeptidase (phytochelatin synthase). Proc Natl Acad Sci USA 86:6838-6842

Hayashi Y, Nakagawa CW, Mutoh N, Isobe M, Goto T (1991) Two pathways in the biosynthesis of cadystins $(\gamma \mathrm{EC})_{n} \mathrm{G}$ in the cell-free extract system of the fission yeast. Biochem Cell Biol 66:288-295

Kopriva S, Muheim R, Koprivova A, Trachsel N, Catalano C, Suter M, Brunold C (1999) Light regulation of assimilatory sulphate reduction in Arabidopsis thaliana. Plant J 20: $37-44$

Koprivova A, Suter M, Op den Camp R, Brunold C, Kopriva S (2000) Regulation of sulfate assimilation by nitrogen in Arabidopsis. Plant Physiol 122:737-746

Le Gall CA, van den Berg CMG (1998) Folic acid and glu- 
tathione in the water column of the north east Atlantic. Deep-Sea Res Part I 45:1903-1918

Leal MFC, Vasconcelos MTSD, van den Berg CMG (1999) Copper-induced release of complexing ligands similar to thiols by Emiliania huxleyi in seawater cultures. Limnol Oceanogr 44:1750-1762

Li ZS, Lu YP, Zhen RG, Szczypka M, Thiele DJ, Rea PA (1997) A new pathway for vacuolar cadmium sequestration in Saccharomyces cerevisiae: YCF1-catalyzed transport of bis(glutathionato) cadmium. Proc Natl Acad Sci USA 94: $42-47$

Marrs KA (1996) The functions and regulation of glutathioneS-transferases in plants. Annu Rev Plant Physiol Plant Mol Biol 47:127-158

Matrai PA, Vetter RD (1988) Particulate thiols in coastal waters: the effect of light and nutrients on their planktonic production. Limnol Oceanogr 33:624-631

Mehra RK, Kodati VR, Abdullah R (1995) Chain lengthdependent $\mathrm{Pb}(\mathrm{II})$-coordination in phytochelatins. Biochem Biophys Res Commun 215:730-736

Newton GL, Dorian R, Fahey RC (1981) Analysis of biological thiols: derivatization with monobromobimane and separation by reverse-phase high-performance liquid chromatography. Anal Biochem 114:383-387

Ortiz DF, Ruscitti T, McCue KF, Ow DW (1995) Transport of metal-binding peptides by HMT1, a fission yeast ABC-type vacuolar membrane protein. J Biol Chem 270: 4721-4728

Parsons TR, Maita Y, Lalli CM (1984) A manual of chemical and biological methods for seawater analysis. Pergamon Press, Oxford

Price NM Harrison GI, Hering JG, Hudson RJ and 3 others (1988/89) Preparation and chemistry of the artificial algal culture medium Aquil. Biol Oceanogr 6:443-461

Rabenstein DL (1989) Metal complexes of glutathione and their biological significance. In: Dolphin D, Avramovic O, Poulson R (eds) Glutathione: chemical, biochemical, and medical aspects. John Wiley \& Sons, New York, p 147-186

Rauser WE, Schupp R, Rennenberg H (1991) Cysteine, $\gamma$-glutamylcysteine, and glutathione levels in maize seedlings. Plant Physiol 97:128-138

Reese RN, Winge DR (1988) Sulfide stabilization of the Cd- $\gamma$-glutamyl peptide complex of Schizosaccharomyces pombe. J Biol Chem 1988:12832-12835

Rijstenbil JW, Wijnholds JA (1996) HPLC analysis of nonprotein thiols in planktonic diatoms: pool size, redox state and response to copper and cadmium exposure. Mar Biol 127: $45-54$

Rijstenbil JW, Dehairs F, Ehrlich R, Wijnholds JA (1998) Effect of the nitrogen status on copper accumulation and pools of metal-binding peptides in the planktonic diatom Thalassiosira pseudonana. Aquatic Toxicol (Amst) 42:187-209

Editorial responsibility: Otto Kinne (Editor), Oldendorf/Luhe, Germany
Ruegsegger A, Schmutz D, Brunold C (1990) Regulation of glutathione synthesis by cadmium in Pisum sativum L. Plant Physiol 93:1579-1584

Salt DE, Rauser WE (1995) MgATP-dependent transport of phytochelatin across the tonoplast of oat roots. Plant Physiol 107:1293-1301

Salt DE, Wagner GJ (1993) Cadmium transport across tonoplast of vesicles from oat roots: evidence for a $\mathrm{Cd} 2+/ \mathrm{H}+$ antiport activity. J Biol Chem 268:12297-12302

Schäfer HJ, Haag-Kerwer A, Rausch T (1998) cDNA cloning and expression analysis of genes encoding GSH synthesis in roots of the heavy-metal accumulator Brassica juncea L.: evidence for Cd-induction of a putative mitochondrial $\gamma$-glutamylcysteine synthetase isoform. Plant Mol Biol 37: $87-97$

Strasdeit H, Duhme AK, Kneer R, Zenk MH, Hermes C, Nolting HF (1991) Evidence for discrete Cd(SCys) $)_{4}$ units in cadmium phytochelatin complexes from EXAFS spectroscopy. J Chem Soc Chem Commun 16:1129-1130

Sunda WG, Huntsman SA (1995) Regulation of copper concentration in the oceanic nutricline by phytoplankton uptake and regeneration cycles. Limnol Oceanogr 40: 132-137

Sunda WG, Huntsman SA (1998) Control of Cd concentrations in a coastal diatom by interactions among free ionic $\mathrm{Cd}, \mathrm{Zn}$, and $\mathrm{Mn}$ in seawater. Environ Sci Technol 32: 2961-2968

Tang D, Hung CC, Warnken KW, Santschi PH (2000) The distribution of biogenic thiols in surface waters of Galveston Bay. Limnol Oceanogr 45:1289-1297

Vasconcelos MTSD, Leal MFC (2001) Adsorption and uptake of $\mathrm{Cu}$ by Emiliania huxleyi in natural seawater. Environ Sci Technol 35:508-515

Vatamaniuk OK, Mari S, Lu YP, Rea PA (2000) Mechanism of heavy metal ion activation of phytochelatin (PC) synthase - blocked thiols are sufficient for PC synthase-catalyzed transpeptidation of glutathione and related thiol peptides. J Biol Chem 275:31451-31449

Weber D, Shaw III CF, Petering DH (1988) Properties of structure and function of cadmium-binding proteins/peptides from Euglena gracilis. Mar Environ Res 24:159-162

Westall JC, Zachary JL, Morel FMM (1976) MINEQL: a computer program for the calculation of chemical equilibrium composition of aqueous systems. RM Parsons Laboratory, Massachusetts Institute of Technology, Cambridge, MA

Zhou J, Goldsbrough PB (1995) Structure, organization and expression of the metallothionein gene family in Arabidopsis. Mol Gen Genet 248:318-328

Zhu Y, Pilon-Smits E, Jouanin L, Terry N (1999) Overexpression of glutathione synthetase in Indian mustard enhances cadmium accumulation and tolerance. Plant Physiol 119: $73-79$

Submitted: March 23, 2001; Accepted: August 9, 2001 Proofs received from author(s): April 9, 2002 